JURNAL PENDIDIKAN, p-ISSN 2715-095X, e-ISSN 2686-5041

Volume 30, No.1, Maret 2021 (59-66)

Online: http://journal.univetbantara.ac.id/index.php/jp

\title{
Upaya Peningkatan Keaktifan Siswa Melalui Pembelajaran Daring dengan Menggunakan Media Google Classroom
}

\author{
Farida Kusumaningrum, Salzabela Agustina, Afif Afghohani ${ }^{\mathrm{CA}^{*}}$ \\ Program Studi Pendidikan Matematika, Fakultas Keguruan dan Ilmu Pendidikan, \\ Universitas Veteran Bangun Nusantara Sukoharjo \\ Jl. Lenjend. Sudjono Humardhani No. 1 Sukoharjo-Jawa Tengah \\ e-mail: salzabelaagustina641@gmail.com \\ CA* $^{*}$ Corresponding Author
}

\begin{abstract}
Abstrak: Penelitian ini bertujuan untuk mengetahui peningkatan keaktifan siswa melalui pembelajaran daring dengan menggunakan media Google Classroom. Penelitian ini dilaksanakan di kelas X MIPA 3 SMA Negeri 1 Polokarto Sukoharjo pada semester ganjil tahun Pelajaran 2020/2021. Penelitian ini merupakan Penelitian Tindakan Kelas. Penelitian Tindakan Kelas menggunakan pembelajaran daring dengan Google Classroom. Hasil penelitian ini adalah Rata-Rata Keaktifan siswa pada Prasiklus sebesar 41,76\%, pada siklus I sebesar $50,58 \%$ dan pada siklus II sebesar $65,29 \%$. Pada siklus II indikator kinerja sudah terlampaui, maka penelitian ini berhenti pada siklus II. Kesimpulan dari penelitian ini adalah pembelajaran daring dengan Google Classroom dapat meningkatkan aktivitas belajar siswa.
\end{abstract}

Kata-kata Kunci: keaktifan siswa, media Google Classroom, pembelajaran daring

\section{Efforts to Increase Student Activeness Through Online Learning Using Google Classroom Media}

\author{
Farida Kusumaningrum, Salzabela Agustina, Afif Afghohani ${ }^{{ }^{*}}$ \\ Mathematics Education Study Program, Faculty of Teacher Training and Education, \\ Bangun Nusantara Sukoharjo Veteran University \\ Jl. Lenjend. Sudjono Humardhani No. 1 Sukoharjo - Central Java \\ e-mail: salzabelaagustina641@gmail.com \\ CA* Corresponding Author
}

\begin{abstract}
This study aims to determine the increase in student activity through online learning using Google Classroom media. This research was conducted in class X MIPA 3 SMA Negeri 1 Polokarto Sukoharjo in the odd semester of the 2020/2021 academic year. This research is a Classroom Action Research. Classroom Action Research uses online learning with Google Classroom. The results of this study were the average activity of students in the pre-cycle was $41.76 \%$, in the first cycle was $50.58 \%$ and in the second cycle was $65.29 \%$. In the second cycle the performance indicators have been exceeded, so this research stops in the second cycle. The conclusion of this study is that online learning with Google Classroom can improve student learning activities.
\end{abstract}

Key words: student activity, Google Classroom media, online learning 


\section{Pendahuluan}

Menurut Edgar Dale dalam Karli \& Sriyuliariatiningsih (2004), pendidikan adalah suatu usaha yang dilakukan dengan sadar oleh masyarakat atau pemerintah melalui bimbingan, pengajaran, pembelajaran, dan pelatihan yang berlangsung, baik dilakukan di sekolah maupun diluar sekolah sepanjang hidup untuk mempersiapkan peserta didik agar dapat menjalankan perannya dalam lingkungan untuk masa yang akan datang. Tujuan pembelajan secara efektif dapat tercapai apabila dalam proses belajar mengajar siswa mendapatkan pengetahuan yang bermakna dan terjadinya tingkah laku yang dapat dicapai dengan partisipasi aktif siswa dalam pembelajaran. Peserta didik selalu menginginkan peningkatan prestasi dalam pendidikannya, prestasi belajar ditentukan oleh proses belajar, semakin siswa senang belajar maka kemungkinan prestasinya juga baik. Proses pembelajaran yang baik ditentukan oleh beberapa faktor, faktor-faktor tersebut dikelola oleh sekolah melalui sebuah manajemen pendidikan. Manajemen pendidikan digunakan untuk mengelola unsur-unsur didalamnya, Sumber Daya Manusia (SDM), proses pembelajaran, dan sarana prasarana merupakan unsur-unsur penting manajemen pendidikan selain kurikulum, dana, informasi dan lingkungan kondusif. (Mulyasa, 2004:13-23). Selain proses belajar mengajar evaluasi juga harus diperhatikan (Suwarto, 2017).

Dalam kondisi pandemi COVID-19 saat ini mengakibatkan terhambatnya semua kegiatan pada berbagai bidang. Khususnya di bidang pendidikan, yang semulanya semua proses belajar dan mengajar dilakukan dengan cara tatap muka sekarang harus menggunakan pembelajaran jarak jauh dengan memaksimalkan teknologi yang ada (Suyahman, 2020). Awalnya cukup sulit untuk melakukan pembelajaran jarak jauh, karena dalam proses belajar dan mengajar guru tidak bisa melihat langsung bagaimana respon para siswa dalam menerima pembelajaran yang diberikan. Kemudian keaktifan siswa juga banyak yang menurun karena berbagai macam hal seperti perangkat handphone yang kurang mendukung untuk melakukan pembelajaran jarak jauh, kendala signal internet yang tidak stabil, dan pembelajaran jarak jauh yang kurang menarik. Dengan berbagai macam kendala yang dialami oleh guru dan siswa seperti yang dijelaskan di atas, maka disini guru melakukan inovasi kembali dalam melakukan proses belajar dan mengajar. Banyak macam media yang ada untuk membantu meningkatkan prestasi belajar siswa, salah satunya media Google Classroom.

Google Classroom (Ruang Kelas Google) adalah suatu serambi aplikasi pembelajaran campuran secara online yang dapat digunakan secara gratis. Pendidik bisa membuat kelas mereka sendiri dan membagikan kode kelas tersebut atau mengundang para siswanya. Google Classroom ini diperuntukkan untuk membantu semua ruang lingkup pendidikan yang membantu siswa untuk menemukan atau mengatasi kesulitan pembelajaran, membagikan pelajaran dan membuat tugas tanpa harus hadir ke kelas. Tujuan utama Google Classroom adalah untuk merampingkan proses berbagi file antara guru dan siswa Google Classroom menggabungkan Google Drive untuk pembuatan dan distribusi penugasan, Google Docs, Sheets, Slides untuk penulisan, Gmail untuk komunikasi, dan Google Calendar untuk penjadwalan. Siswa dapat diundang untuk 
bergabung dengan kelas melalui kode pribadi, atau secara otomatis diimpor dari domain sekolah. Setiap kelas membuat folder terpisah di Drive masing-masing pengguna, dimana siswa dapat mengirimkan pekerjaan untuk dinilai oleh guru. Aplikasi ini tersedia bagi pengguna seluler perangkat iOS dan Android yang memungkinkan pengguna mengambil foto dan melampirkan penugasan, berbagi file dari aplikasi lain dan mengakses informasi secara offline. Guru dapat memantau kemajuan untuk setiap siswa, dan setelah dinilai, guru dapat kembali bekerja bersama dengan komentar.(Anonim, 2020)

Tujuan Penelitian ini adalah untuk mengetahui peningkatan keaktifan siswa melalui pembelajaran daring dengan menggunakan media Google Classroom pada siswa kelas X MIPA 3 SMA N 1 Polokarto Sukoharjo di semester ganjil tahun pelajaran 2020/2021.

\section{Metode Penelitian}

Penelitian ini adalah penelitian tindakan kelas. Objek dalam penelitian ini adalah siswa kelas X MIPA 3 semester ganjil SMA N 1 Polokarto tahun pelajaran 2020 / 2021 yang dilakukan langsung oleh peneliti dibantu oleh teman sejawat yang ikut mengamati jalannya penelitian terdiri dari 34 siswa. Dalam penelitian ini terdapat 2 varabel yaitu pembelajaran online media Google Classroom (variabel bebas) dan keaktifan belajar siswa (variabel terikat).

Jenis penelitian ini adalah penelitian tindakan kelas, yang meliputi empat tahap yaitu 1). Perencanaan yang terdiri dari pengamatan terhadap hasil belajar siswa pada pertemuan yang lalu, mengidentifikasi faktor-faktor yang mempengaruhi kegiatan belajar siswa, perencanaan tindakan yang akan dilaksanakan dan menyiapkan perangkat-perangkat pembelajaran yang akan digunakan. 2). Pelaksanaan penelitian yaitu kegiatan pembelajaran di kelas seperti yang telah disusun dalam rencana pelaksanaan pembelajaran. 3). Pengamatan dilaksanakan saat kegiatan kedua dilaksanakan. Kedua tahap ini tidak dapat dipisahkan karena akan mempengaruhi hasil akhir penelitian. 4). Refleksi. Kegiatan ini dilaksanakan untuk mengungkapkan kembali apa yang telah dilakukan. Kegiatan yang dilakukan adalah mengobservasi kelemahan dan kekurangan kegiatan pada siklus I, menyusun rencana perbaikan pada siklus II. Demikian menurut Suharsimi Arikunto dalam Jalil $(2014 ; 11)$

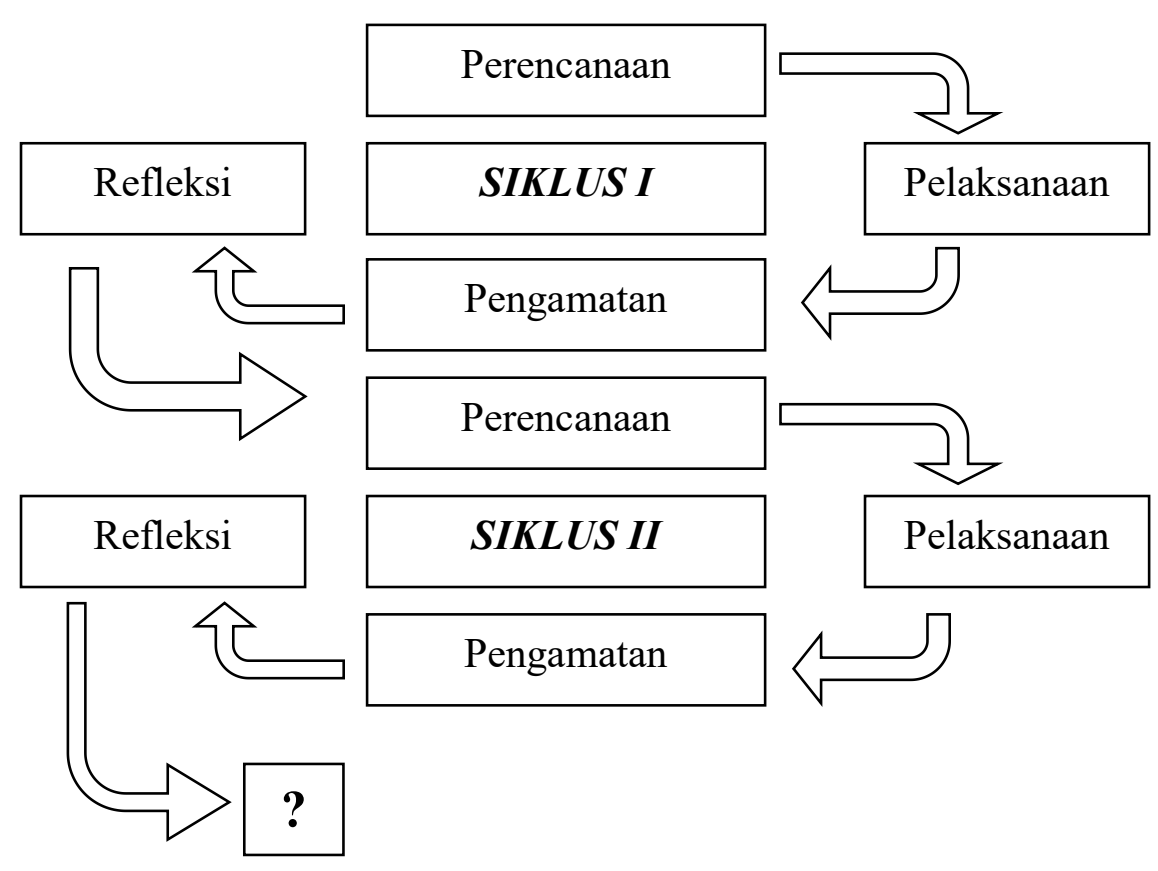




\section{Gambar 1: Siklus PTK}

Data lapangan dikumpulkan melalui observasi dan data dokumentasi. Lembar observasi digunakan untuk mencari data tentang proses pelaksanaan model pembelajaran dan tingkat keaktifan siswa pada kegiatan pra siklus dan kegiatan siklus I maupun siklus II, lembar observasi diisi oleh guru maupun kolaborator. Metode yang kedua adalah studi dokumentasi, metode ini digunakan peneliti untuk menggali dokumen-dokumen pendukung yang digunakan untuk melengkapi data keaktifan siswa, dokumen yang digunakan adalah buku catatan siswa dan bukti catatan pengumpulan tugas.

Adapun rumus data persentase keaktifan belajar siswa adalah sebagai berikut:

$P=\frac{\mathrm{f}}{\mathrm{N}} x 100 \%$

Keterangan :

$\mathrm{P}=$ Angka persentase

$\mathrm{f}=$ Frekuensi yang sedang dicari persentasenya

$\mathrm{N}=$ Number of case (Anas Sudijono, 2006:43)

Indikator kinerja yang ingin diperoleh dalam penelitian tindakan kelas ini adalah meningkatnya keaktifan belajar Matematika pada siswa kelas X MIPA 3 SMA N 1 Polokarto Sukoharjo. Sebagai ukuran keberhasilan pelaksanaan penelitian tindakan kelas ini adalah jika keaktifan belajar siswa melebihi 65\%. Data yang didapatkan dalam penelitian ini yaitu keaktifan belajar siswa pada kegiatan pembelajaran Pra siklus, Siklus I, dan Siklus II. Data tersebut diolah dengan menggunakan rumus data persentase keaktifan belajar siswa. Dapat dilihat pada table dibawah ini.

Tabel 1. Indikator Kinerja

\begin{tabular}{ll}
\hline Kriteria Penilaian & Kualifikasi \\
\hline$>65 \%$ & Berhasil \\
$<65 \%$ & Tidak Berhasil \\
\hline
\end{tabular}

\section{Hasil Penelitian}

Pelaksanaan pembelajaran pra siklus menggunakan WhatsApp Web dengan pembelajaran yang berpusat pada guru, dimana guru sebagai pusat informasi, guru menggunakan metode ceramah yang diselingi demonstrasi dan tanya jawab dalam proses pembelajaran. Pengamat mengamati keaktifan siswa dengan lembar observasi dengan lima indikator keaktifan. Hasil observasi menunjukkan bahwa indikator pertama yaitu perhatian sebesar 85,29\%, indikator kerjasama dan hubungan sosial sebesar 26,47\%, indikator selanjutnya mengemukakan pendapat atau ide sebesar 5,88\%, sedangkan indikator 
pemecahan masalah sebesar $11,76 \%$ dan indikator terakhir yaitu disiplin sebesar 79,41\%. Instrumen keaktifan di atas dapat disimpulkan bahwa keaktifan siswa yang dilihat dari indikator perhatian dan disiplin sudah melebihi $65 \%$ namun dari instrumen kerjasama dan hubungan sosial, pendapat dan ide, pemecahan masalah belum melebihi $65 \%$ sehingga dapat disimpulkan bahwa keaktifan siswa belum seluruhnya aktif.

Siklus I dalam penelitian ini dengan menerapkan pembelajaran daring dengan media Google Classroom, pelaksanaan tindakan dilakukan dalam mengatasi permasalahan tingkat keaktifan siswa yang rendah dengan melaksanakan proses belajar mengajar oleh pelaku tindakan dan dilakukan pengamatan oleh pengamat atas segala yang terjadi pada saat pelaksanaan tindakan. Siklus pertama ini terdiri dari empat macam yaitu: perencanaan, pelaksanaan, pengamatan dan refleksi. Pengamatan dilakukan untuk mengamati keaktifan siswa berdasarkan lembar observasi. Data observasi pada siklus ini menunjukkan indikator pertama yaitu perhatian sebesar $85,29 \%$, indikator kedua tentang kerjasama dan hubungan sosial sebesar 35,29\%, indikator mengemukakan pendapat atau ide sebesar $26,47 \%$ indikator keempat tentang pemecahan masalah sebesar $23,52 \%$ dan indikator disiplin sebesar $82,35 \%$, jika disajikan pada tabel terlihat seperti Tabel 2 .

Tabel 2. Persentase keaktifan belajar pada Pra siklus dan siklus I

\begin{tabular}{clcc}
\hline NO & \multicolumn{1}{c}{ Indikator } & Pra siklus & Siklus I \\
\hline 1 & Perhatian & $85,29 \%$ & $85,29 \%$ \\
2 & Kerjasama dan Hubungan Sosial & $26,47 \%$ & $35,29 \%$ \\
3 & Mengemukakan Pendapat atau Ide & $5,88 \%$ & $26,47 \%$ \\
4 & Pemecahan Masalah & $11,76 \%$ & $23,52 \%$ \\
5 & Disiplin & $79,41 \%$ & $82,35 \%$ \\
\hline & & $41,76 \%$ & $50,58 \%$ \\
\hline
\end{tabular}

Sedangkan dari data studi dokumentasi pengumpulan tugas untuk data ketiga keaktifan menunjukkan bahwa sebesar 28 dari 34 siswa atau sebesar $82,35 \%$ mengumpulkan tugas tepat waktu. Siklus kedua ini terdiri dari tiga rangkaian yaitu: perencanaan, tindakan dan pengamatan dan refleksi. Berdasarkan data yang diperoleh dari proses kegiatan belajar mengajar pada siklus I, maka dibuatlah perencanaan tindakan dari siklus II. Kolaborator melakukan observasi dengan instrumen dan mengisi lembar observasi untuk mencari dan mengumpulkan data selama proses pembelajaran.

Refleksi merupakan upaya untuk mengkaji apa yang telah terjadi dan atau tidak terjadi pada saat pelaksanaan tindakan. Hasilnya digunakan untuk menetapkan tindak lanjut penelitian termasuk perubahan tindakan yang mungkin diambil bila siklus sebelumnya belum mampu mengatasi persoalan. Data hasil observasi pada siklus kedua ditunjukkan pada tabel di bawah ini Tabel 3. Skor keaktifan siswa siklus II berdasarkan instrumen observasi. 
Tabel 3. Persentase keaktifan belajar pada Pra siklus, siklus I dan siklus II

\begin{tabular}{clccc}
\hline NO & \multicolumn{1}{c}{ Indikator } & Pra siklus & Siklus I & Siklus II \\
\hline 1 & Perhatian & $85,29 \%$ & $85,29 \%$ & $85,29 \%$ \\
2 & Kerjasama dan Hubungan Sosial & $26,47 \%$ & $35,29 \%$ & $55,88 \%$ \\
3 & Mengemukakan Pendapat atau Ide & $5,88 \%$ & $26,47 \%$ & $52,94 \%$ \\
4 & Pemecahan Masalah & $11,76 \%$ & $23,52 \%$ & $50,00 \%$ \\
5 & Disiplin & $79,41 \%$ & $82,35 \%$ & $82,35 \%$ \\
\hline & & $41,76 \%$ & $50,58 \%$ & $65,29 \%$ \\
\hline
\end{tabular}

Data dari lembar observasi menunjukkan bahwa kelima indikator sudah mencapai skor $>50 \%$ dari skor maksimal. Data pada siklus kedua menunjukkan bahwa siswa teridentifikasi mulai meningkat keaktifannya jika dilihat dari lima indikator keaktifan siswa tersebut seluruhnya dapat berkontribusi penuh dalam keaktifnya di pembelajaran. Berdasarkan Tabel 3 dapat digambarkan dalam histogram sebagai berikut.

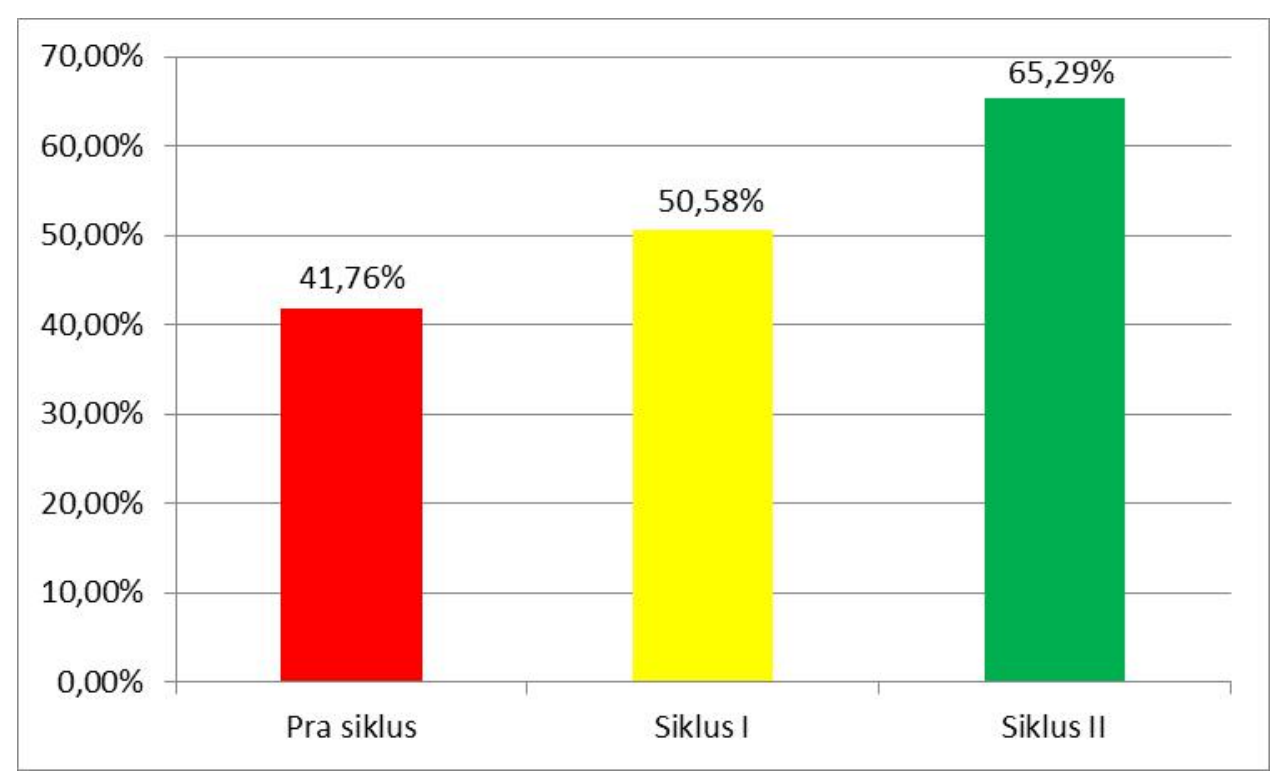

Gambar 2. Diagram rata-rata persentase keaktifan siswa Pra siklus, siklus I, dan siklus II Pembahasan 
Dari hasil penelitian diperoleh bahwa pembelajaran daring dengan menggunakan google classroom dapat meningkatkan aktifitas belajar siswa yang selanjutnya diharapkan juga dapat meningkatkan prestasi belajar mereka. Dalam pembelajaran ini peneliti membuat materi bahan ajar yang telah disesuaikan secara jelas dan dapat dipahami oleh siswa, sehingga siswa dapat belajar dengan mudah. Kemudian mengunggah materi tersebut ke dalam aplikasi google classroom. Hasil yang diperoleh ini sesuai dengan hasil yang serupa yang telah dilakukan oleh peneliti lain dengan judul Penggunaan Aplikasi Google Classroom dalam Upaya Meningkatkan Hasil Belajar Matematika pada Siswa Kelas X SMA Jurusan IPS (Darmawan, 2019). Pemanfaatan Google Classroom dapat melalui multiplatform yakni dapat melalui komputer dan dapat melalui gawai. Google Classroom merupakan sebuah aplikasi yang memungkinkan terciptanya ruang kelas di dunia maya. Selain itu, google classroom bisa menjadi sarana distribusi tugas, submit tugas bahkan menilai tugas-tugas yang dikumpulkan.

Hakim mengatakan bahwa Google Classroom dirancang untuk mempermudah interaksi guru dan siswa dalam dunia maya. Aplikasi ini memberikan kesempatan kepada guru untuk mengeksplorasi gagasan keilmuan yang dimilikinya kepada siswanya. Guru memiliki keleluasaan waktu untuk membagikan materi pelajaran dan memberikan tugas mandiri kepada siswa. Guru juga dapat membuka ruang diskusi bagi para siswa secara online. Melalui aplikasi Google Classroom diasumsikan bahwa tujuan pembelajaran akan lebih mudah direalisasikan dan sarat kebermaknaan. Oleh karena itu, penggunaan Google Classroom ini sesungguhnya mempermudah guru dalam mengelola pembelajaran dan menyampaikan informasi secara tepat dan akurat kepada peserta didik (Hakim, 2016:58).

\section{Simpulan dan Saran}

Berdasarkan data hasil penelitian didapatkan kesimpulan bahwa pembelajaran daring dengan menggunakan Google Classroom dapat meningkatkan keaktifan belajar siswa kelas X MIPA 3 SMA N 1 Polokarto Sukoharjo. Siswa disarankan untuk lebih bersemangat dan bersungguh-sungguh dalam mengikuti pembelajaran sistem daring agar situasi pembelajaran seperti saat ini tidak mengganggu dan menghambat dalam meraih tujuan belajar, baik secara akademis maupun psikologis dan bagi guru disarankan untuk selalu memberikan bimbingan kepada semua siswa.

\section{Daftar Rujukan}

Anonim. (2020). https://idcloudhost.com/mengenal-apa-itu-google-classroom-fitur-fungsidan-keunggulannya. Diakses pada tanggal 24 November 2020.

Darmawan, Yuda. (2019). Penggunaan Aplikasi Google Classroom Dalam Upaya Meningkatkan Hasil Belajar Matematika pada Siswa Kelas X SMA Jurusan IPS. http://eprints.ums.ac.id/76921/12/NASKAH\%20PUBLIKASI.pdf. Diakses pada tanggal 23 Januari 2021.

Hakim, A. B. (2016). Efektifitas Penggunaan E-Learning Moodle, Google Classroom Dan Edmodo. Stimik Esq, 2(1-4), 1-6.

Jalil, Jasman. (2014). Panduan Mudah Penelitian Tindakan Kelas. Jakarta: Prestasi Pustaka Publisher. 
Karli \& Sriyuliariatiningsih. (2004). Implementasi Kurikulum Berbasis Kompetensi ModelModel Pembelajaran. Bandung: Bina Media.

Mulyasa. (2004). Menjadi Guru Profesional Menciptakan Pelajaran Kreatif dan Menyenangkan. Bandung: Remaja Rosda Karya

Sudijono, Anas. (2005). Pengantar evaluasi pendidikan. Jakarta: Raja Grafindo Persada.

Suyahman. (2020). Pelaksanaan Pendidikan Karakter Melalui Gerakan Pramuka di Era Pandemi Covid-19. Jurnal Pendidikan, volume 29(2), Juli 2020, hal: 169-176. http://journal.univetbantara.ac.id/index.php/jp/article/view/803/603

Suwarto, S. (2017). Pengembangan tes ilmu pengetahuan alam terkomputerisasi. Jurnal Penelitian dan Evaluasi Pendidikan, 21(2), 153-161. 